TECHNICAL SCIENCES AND TECHNOLOGIES

UDC 681.51:006.91

DOI: $10.25140 / 2411-5363-2021-2(24)-99-105$

Marek Vagaš, Alena Galajdová

\title{
INDUSTRIAL VISION SYSTEM FOR OBJECT DETECTION
}

The article aimed to experimentally verify and detect the coordinates of a given reference object, which will be manipulated by an industrial robotic arm, type SCARA. It was necessary to identify and locate individual objects at the automated workplace using the OMRON F150-3 visual inspection system during the process. Therefore, the ultimate goal of the assigned task is to reliably grasp the detected reference object and move on to the next technological operation. In the future, it would be appropriate to ensure reliable lighting conditions to guarantee the continuity of the automated process.

The article is a publication of scientific and methodical character.

Keywords: vision system; OMRON F150-3; light condition; automation; SCARA robot; calibration.

Fig.: 9. References: 11

The urgency of the research. Trends in the field of unconventional technologies and their use in multidisciplinary production and automation, in general, are currently directed mainly to the area of advanced sensing and evaluation of parameters of objects participating in these production processes. Therefore, equipping automated production facilities with unconventional technologies is no longer satisfied with the classic use of standard sensor components, mostly part of the robotic arm. Instead, it focuses on the field of materials engineering in the form of advanced 3D vision systems, which allow the use of built-in complex chains of recognition of object characteristics.

Target setting. The existing classical approaches and techniques of selecting the processing of some essential properties of objects are no longer sufficient for the new requirements imposed by both end-users and the requirements of the technological engineering itself. Therefore, the $3 \mathrm{D}$ camera sensor as the leading representative of the vision system is currently an essential element of the production plant's equipment to expand its peripheral capabilities and capabilities in the context of Industry 4.0. In addition, these systems (for industrial image processing) monitor entire processes, optimize them and thus enable error prediction, faster sequences of robotic arm movements with consistent quality.

Actual scientific researches and issues analysis. Currently, ongoing research and development in this area are focused on determining the parameters of a 3D model based on at least two image signal sensors (cameras). It is possible to compile the necessary process data of the scanned object subsequently. A 3D vision system must be incremental in the sense that its elementary process components (tasks) are possible to extend to include new descriptions to represent the model and extract unique features from the images of the scene [1]. In addition, in all technological processes, there is often a situation of irregular arrangement of objects. It is not possible to use a fixed program of the production site and the network layout of system pallets. We can determine the reliability of this inspection by the devices parameters selection such as camera, lens, lighting, P.C., and appropriate software use. The application of machine vision is constantly increasing today, and in practice, we apply it in various application areas [2]. In such (and similar) cases, it is suitable for determining the properties of objects stored, e.g., use a CCD camera on the palette. A typical industrial CCD camera captures and transmits the captured image via a standard camera bus, such as, e.g., Camera Link or IEEE 1394 to a connected P.C. or into image processing systems, which then evaluate these images to obtain helpful information. We concluded that careful analysis of the operation is the most critical issue for getting good results in any process [3]. In addition, intelligent cameras now simplify material engineering even more, as image analysis takes place directly in the camera. Their core is usually a processor that runs a complete set of algorithms needed for vision.

Moreover, these devices must be for immediate and straightforward installation and communication. The main idea is to easily and quickly install these intelligent cameras using the lowest possible connecting cables and building the camera as a modular structure. These features allow optimizing both the cost of the camera and the time and costs for installing the system [4].

(C) Vagaš M., Galajdová A., 2021 
Analysis of existing research and publications. Introduction of an affordable vision system to inspect and implement a systematic approach to managing technological processes. Application of total control (TQM) of each product we realize on the example of manipulation of a selected object from an automated workplace.

Article objective. The purpose of the article is to present this solution as a suitable affordable one, which will serve as a starting point based on the well-known RS232C communication protocol. We currently use it for data processing, acquisition of the scanned image, and subsequent calculations with the help of a powerful computer. Furthermore, we prepare this verified technical set for its future deployment in an actual automated workplace with the participation of a robotic arm of the SCARA type.

General overview of the system. The implementation of experimental activities is an effort to detect the center of gravity of a selected object of an automated workplace with a SCARA robot. Part of these activities is the implementation of measurements, and the aim is to determine the coordinates of the center of gravity of the reference object $(\Phi 15 \times 10)$ (Fig.1).

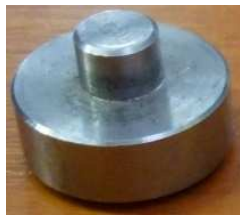

Fig. 1. Reference object for CoG determination

The starting point of the experiments is the realization of a measuring workplace, which will serve for a solid and reliable (structural) mounting of two 2D camera systems, which is very important for the course of experimental measurements. Furthermore, it should be borne in mind that there is a demand for flexibility and convenient adjustment of the lenses of camera systems to different spatial layouts during the experiment process. Variants for capturing a reference object by two 2D camera systems shows Fig.2.
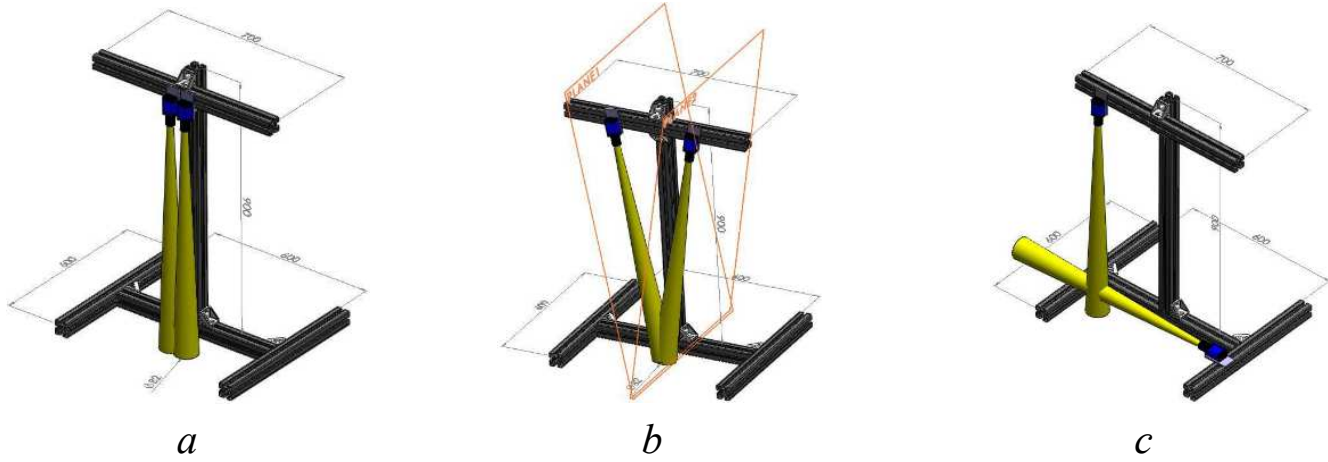

Fig. 2. Measurement layout by two $2 D$ camera system:

$a$-Side by side; $b$-Under some value of the angle; $c$-Rectangular

The reason is the sensing of the reference object at the automated workplace from different angles. Following this, we use the modular aluminum construction profiles $(50 \times 50 \mathrm{~mm})$ to realize the measuring structure. Design "a" is not sufficiently satisfactory because the camera system will not detect the Z-coordinate of the reference object. The embodiment indicated as " $b$ " represents the rotation of both camera systems at a certain angle. This solution enables the detection of the Z-coordinate using a suitable configuration of individual parts concerning the principles of triangulation calculation [5]. The best right and final solution is the third variant, which allows the measurement of the Z-coordinate by measuring the "depth" of the reference object. In this way, we achieve complete information about the 3D characteristic. It is possible to extract the " $x$ " and " $y$ " coordinates of the reference object at the automated workplace from the vertically stored camera system. The third coordinate, "z" (height of the reference object), 
TECHNICAL SCIENCES AND TECHNOLOGIES

can be determined using a horizontal camera system. The resulting experimental set-up comprises a platform (3) on which we place the reference object. We realize the object's placement as the intersection of the field of view from 2D camera systems' lenses (see Fig. 3).

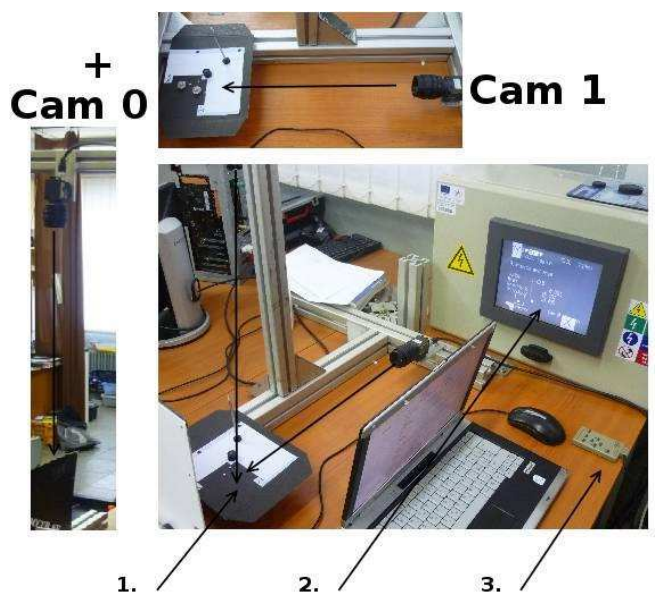

Fig. 3. Measuring set-up

The measuring station includes an LCD panel (2) and a control programming console (3). As a vision system, we use the OMRON F150-3 type [6]. This system belongs to the so-called compact vision systems, consisting of two parts - an image information processing unit (independent from the P.C.) and an externally connected CCD camera, or several CCD cameras. Image information is processed and evaluated in an external pc, outside the CCD cameras. The unit's architecture is usually similar to an industrial or embedded P.C. built on a powerful processor. The key and critical point of any vision system are the specific parameters of the cameras used (Fig. 4). Precisely, three issues. The resolution, field of view, and lens focal length.

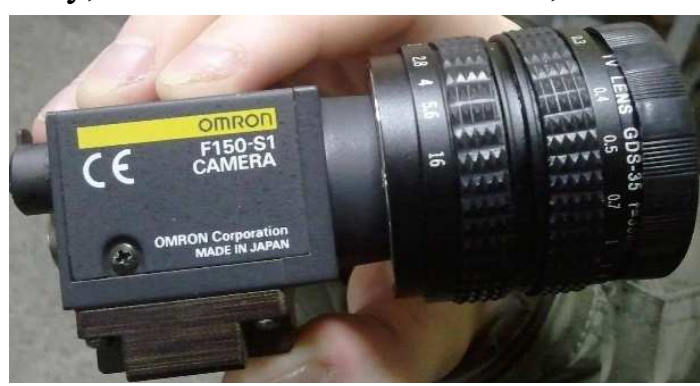

Fig. 4. Camera F150-S1 with $35 \mathrm{~mm}$ CCTV lens

The resolution of the F150-3 camera system is $512(\mathrm{H}) \times 484(\mathrm{~V})$, and the camera itself is $659(\mathrm{H}) \times 494(\mathrm{~V})$. The focal length of the lenses in the mounted lens is $35 \mathrm{~mm}$. The range of the image depends on the intelligent light source (if the fit is attached to the camera), the distance between the measured object and the camera, or an intermediate piece (the additional intermediate link between the camera itself and the camera itself lens) [7]. In our case, no other light source or middle element was used. The set-up of the vision system is focused on the interconnection supported by the use of available communication protocols and interfaces so that reliable communication between the control system of the robotic arm and the vision system is achieved. Existing communication interfaces are created based on the connectivity and the topology as Ethernet, RS232, RS485, RS422, CAN-bus, and PROFIBUS [8]. From the software point of view, for a robotic arm, it is necessary consisting of libraries together with reliable functions for the communication (with the vision system) inside their control system. 
TECHNICAL SCIENCES AND TECHNOLOGIES

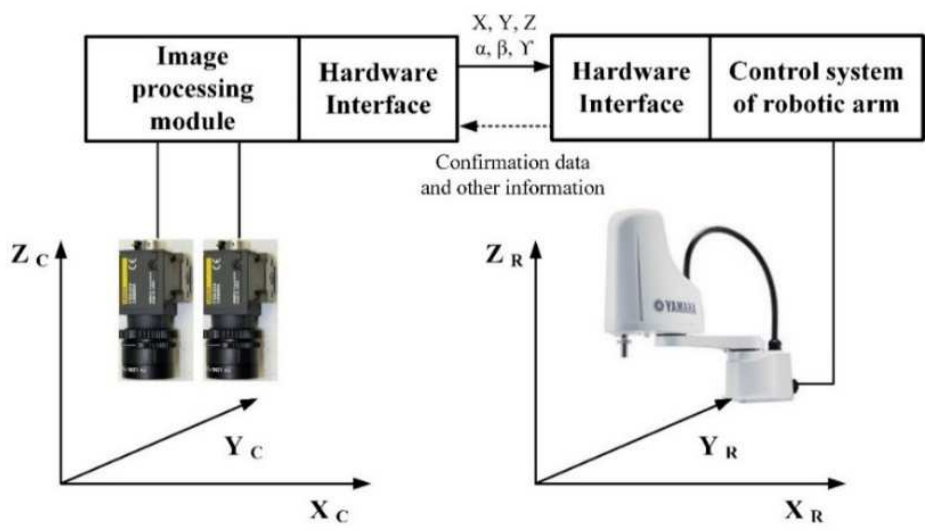

Fig. 5. Camera F150-S1 with 35mm CCTV lens

The interconnection between the control system of the robotic arm and the vision system can be seen in Fig. 5. The next logical step consists of the vision system calibration. Its purpose is to determine internal, external parameters and the values of the mathematical model for the lens distortion (due to their impact). Using the calibration process, we determine the precise position selection of the entities from the pictures. This process is followed by the transformation between relationships of the robotic arm coordinate system and the vision system. As part of the measurement chain, the camera system needs to define its internal and external parameters to obtain input data $(\mathrm{x}, \mathrm{y}, \mathrm{z})$ [9]. For this purpose, it is necessary to calibrate the camera system. In this article, we have dealt with the one-dimensional calibration method of objects. For these objects, we do not know the properties of the points or the distances between them. To use this method of calibration points lying in the plane, we need to ensure stable parameters of these points. Using a very accurate digital meter (digital multimeter), the coordinates (in $\mathrm{mm}$ ) were verified for calibration point No. 1: $[\mathrm{x}=30.000, \mathrm{y}=20.000]$, for calibration point No. 2 the coordinates (in $\mathrm{mm}$ ): $[\mathrm{x}=15.000, \mathrm{y}=15.000]$. Since the magnification scale is the same in both the , $\mathrm{x}^{\text {“ }}$ and „, $\mathrm{y}^{\text {“ }}$ axes, two points are sufficient for calibration (Fig. 6).

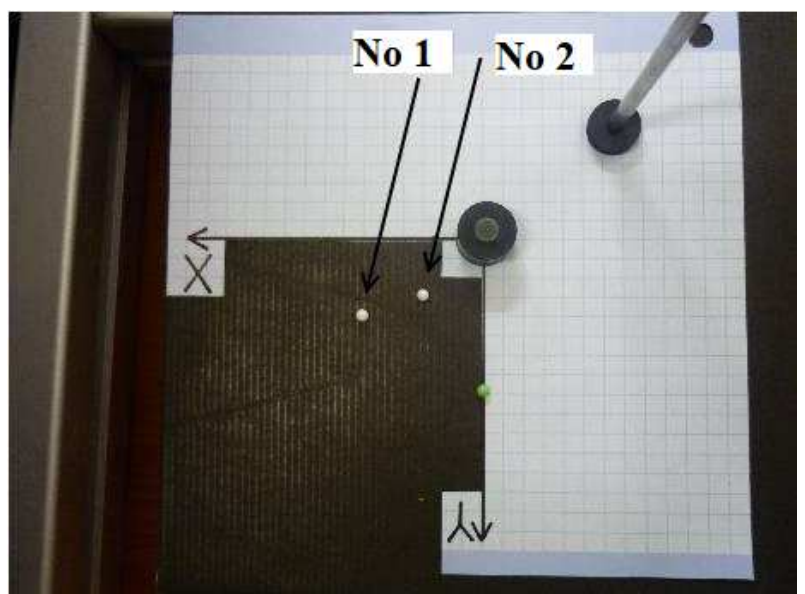

Fig. 6. Calibration of the vertical part (CCD camera 1) of the vision system OMRON F150-3

Calibration of the horizontal part (CCD camera 2) of the vision system we realize by an analogous procedure. Still, in this case, we are only interested in the " $z$ " - the new (at the given set of the camera coordinate system) (Fig. 7). 
TECHNICAL SCIENCES AND TECHNOLOGIES

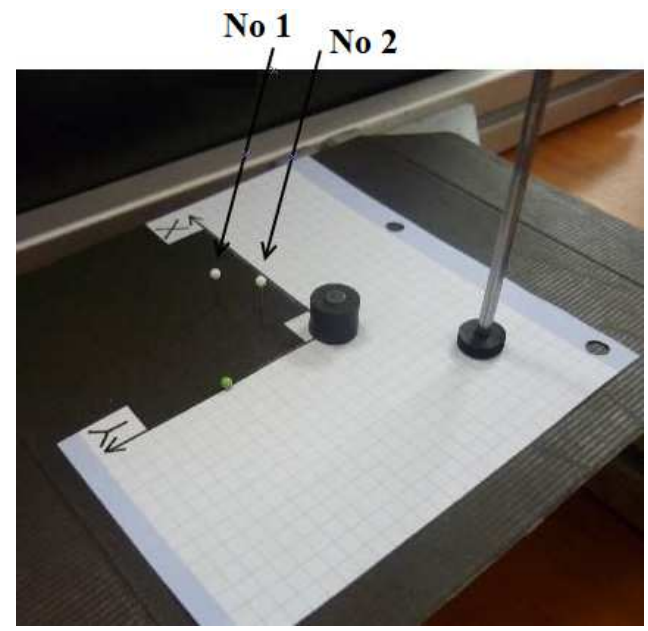

Fig. 7. Calibration of the horizontal part (CCD camera 2) of the vision system OMRON F150-3

The "Density Averaging" function (based on the differences in the brightness of the image units) we use to determine whether the reference object (whose center of gravity coordinates we want to identify) is at all on the measurement scene. In this measurement, the density of each pixel is evaluated based on its brightness. (Values from 0 to 255 , the so-called grayscale.) We then calculate the total average for the search region. A measurement is made based on the estimated value - the average optical density of the area without the measured object. Detection of the sensed object gives us qualitative information about errors from the measurement by the vision system [10]. The failed measure led us to the returning of the initial recalibration. An identification of coordinate axes , $\mathrm{x}^{\text {“ }}$ and , $\mathrm{y}^{\text {“ }}$ for the sensed object is the next step (by using the gravity and area function). Next to fundamental step consists of calculation the area of the perceived object that is viewed from the top. The sensed object is evaluated by white pixels (mainly, according to the light source), and the other area is black Fig. 8.

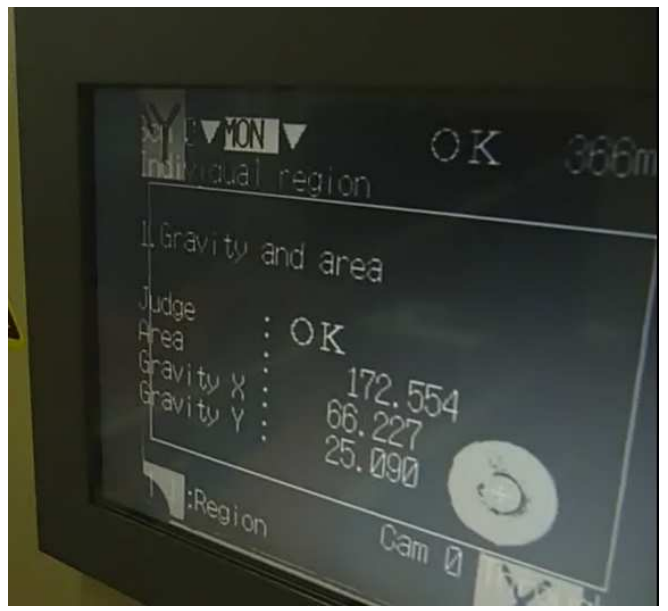

Fig. 8. Determination of " $x$ " and " $y$ " coordinates

The next step consists of ,z-axis determination, the shape, depth, and high of the sensed object (see Fig. 9). Sub-activities of this step also consist of a post-processing process applied to the captured picture from the vision system, and we successfully implement the edge position function at this process. We can characterize this function as the ability to detect the edges of the sensed object, assuming that there is sufficient contrast between the object and the environment. We can evaluate (in the appropriate direction) the edges of a sensed object by applying this process. The aim is the simultaneous usage of the functions "light to dark" (if it is the sensed object dark and background bright) or "dark to light" (if it is the sensed object bright and background dark). 


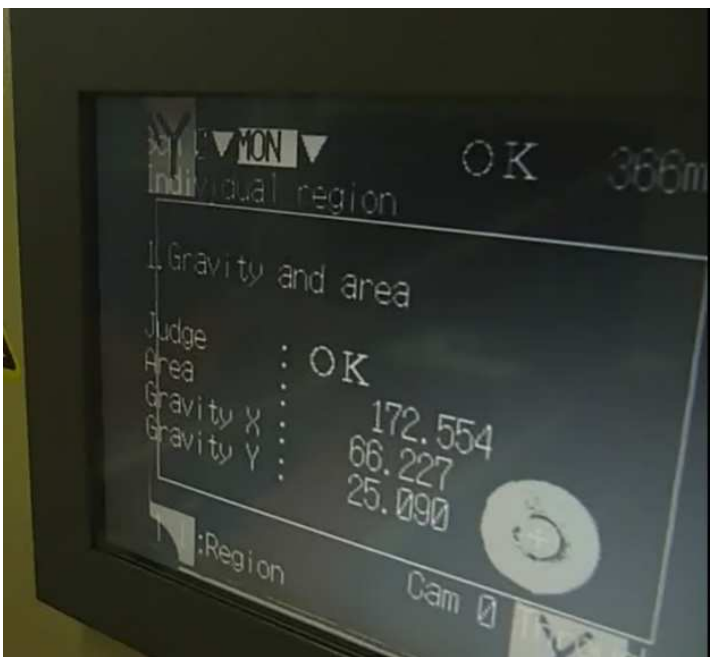

Fig. 9. Determination of " $z$ " coordinate

Finally, the last step consists of determining coordinates of the center of gravity of the sensed object, which we choose by a simple mathematical operation $[\mathrm{x}, \mathrm{y}, \mathrm{z} / 2]-$ because the center of the gravity is determined at the middle of the center, the sensed object. Information obtained by this principle is then transferred into the computer via the RS232C serial interface for their advanced processing (coordinates transformation from external coordinate system to the coordinates of robotic arm control system) [11]. Sub-activities of this step are followed by coordinate information transmitted directly to the control system of the robotic arm.

Conclusions. We can state that a major influence on the captured results has the light conditions (light uniformity) or vertical camera system distance from the sensed object. This research aimed to design a reachable and fully functional vision system based on two standard CCD camera usage. Specifically, our solution is focused on the R.S. 232C communication interface as an interconnection standard between two sites (vision system and robotic system). What is more, such obtained results at the moment are well prepared for their further and deeper processing during the next phase of development.

Acknowledgment. This work is supported by the Slovak Grant VEGA 1/0330/19-Research and design of algorithms and systems to fuse heterogeneous data in multisensor architectures and KEGA 044TUKE-4/2021-Remote access to laboratory exercises for industrial automation.

\section{References}

1. Distante, A.; Distante, C. (2020). Handbook of Image Processing and Computer Vision. Springer Nature: Berlin, 448p. ISBN 978-3-030-42373-0.

2. Vagas, M.; Galajdova, A.; Dzongov, M. (2019). Proposal of a vision system for automated line MPS 500. Technical Sciences and Technologies - Chernihiv National University of Technology. Vol. 18, no 4, p. 109-114. ISSN 2411-5363.

3. Hasegawa, Y.; Shimon, Y. Nof. (2020). Handbook of Automation. Springer - Verlag: Berlin, 1812p. ISBN 978-3-540-78830-0.

4. Frontoni, E.; Mancini, A.; Zingaretti, P. (2015). Embedded Vision Sensor Network for Planogram Maintenance in Retail Environments. MDPI Publishing, Sensors 2015, 15, ISSN 21114-21133.

5. Collado, J. F. (2004). New methods for triangulation-based shape acquisition using laser scanners. Department d'Electronica, Informatica/Automatica, Universitat de Girona. Tesi doctoral, ISBN 84-689-3091-1.

6. OMRON Corporation, Industrial Automation Company. (2004). Operation manual for vision system OMRON F150-3. Retrieved from https://assets.omron.eu/downloads/manual/en/z142_f150v3_expert_menu_operation_manual_en.pdf. 
7. Novak, P.; Spacek, P.; Mostyn, V. (2011). Stereovision system - detection of the corresponding's points. Proceedings of the ICMT 11 - International Conference on Military Technologies, p. 961-968. ISBN 978-80-7231-787-5.

8. Vagas, M.; Sukop, M.; Balaz, V.; Semjon, J. (2012). The calibration issues of the $3 D$ vision system by using two 2D camera sensors. International Scientific Herald, Vol. 3, no. 2, p. 234-237. ISSN 2218-5348.

9. Perez, L.; Rodriguez, I.; Rodriguez, N.; Usamentiaga, R.; Garcia, D.F. (2016). Robot Guidance Using Machine Vision Techniques in Industrial Environments: A Comparative Review. MDPI Publishing, Sensors-Open Access Journal, Vol. 16, p. 335-361. ISSN 1424-8220.

10. Halenar, I.; Juhas, M.; Juhasova, B.; Dmitrii, Vladimirovic, B. (2019). Virtualization of production using digital twin technology. 17th International Carpathian Control Conference (ICCC), p. 1-5. ISBN 978-1-7281-0702-8.

11. Holubek, R.; Ruzarovsky, R.; Delgado Sobrino, D.R. (2019). An innovative approach of industrial robot programming using virtual reality for the design of production systems layout. Advances in Manufacturing - Springer Nature Switzerland AG, p. 223-235. ISBN 978-3-030-18714-9.

УДК 681.51:006.91

\section{Марек Вагаш, Алена Галайдова}

\section{СИСТЕМА ПРОМИСЛОВОГО БАЧЕННЯ ДЛЯ ВИЯВЛЕННЯ ОБ'СКТІВ}

Тенденції в області нетрадиџійних технологій та їх використання в багатопрофільному виробництві та автоматизації в даний час направлені в основному на ідентифікацію та оцінку параметрів об'єктів, щяо беруть участь у виробничих процесах. Сучасне оснащення автоматизованих промислових об'єктів нетрадиційними технологіями фокусується на галузі інженерії матеріалів у вигляді передових систем тривимірного зору, які дозволяють використовувати вбудовані складні ланиюжски розпізнавання характеристик об'єкта.

Стаття спрямована на експериментальну перевірку і визначення координат заданого еталонного об'єкта, яким управлятиме промисловий робот-маніпулятор типу SCARA. У проиесі роботи необхідно було ідентифікувати $і$ локалізувати окремі об'єкти на автоматизованому робочому місиі за допомогою системи візуального контролю OMRON F150-3. Тому кінцева мета поставленого завдання - надійно ідентифікувати виявлений еталонний об'єкт $i$ перейти до наступної технологічної операциї.

Показано, щчо основний вплив на отримані результати ідентіфікаиіi об'єктів здійснюють умови освітлення (рівномірність освітлення) або відстань системи вертикальної камери від виявленого об'єкту. Результати дослідження були спрямовані на створення доступної і повністю функціональної системи технічного зору, заснованої на використанні двох стандартних камер CCD $і$ застосуванні комунікаційного інтерфейсу RS232C як стандарту взаємодіі між двома об'єктами (система технічного зору і роботизована система). Отримані на даний момент результати адаптовані для подальшого, більш глибокого опрацювання на наступному етапі розробки. Зокрема, дочільно забезпечити надійні умови освітлення, щоб гарантувати безперервність автоматизованого процесу.

Опублікована стаття представляє вибрані кроки для отримання даних еталонного об'єкта (зокрема, иентру ваги) з акиентом на виробника систем камер OMRON. Представлена стаття надає більш детальне уявлення про систему розпізнавання та калібрування зображення, яке часто недостатньо повно описується в посібниках постачальників.

Стаття є публікаиією науково-методичного характеру.

Ключові слова: система зору; OMRON F150-3; стан світла; автоматизачія; Робот SCARA; калібрування.

Рис.: 9. Бібл.: 11.

Marek Vagas - Doctor of Technical Sciences, Associate Professor, Technical University of Kosice, Faculty of Mechanical Engineering, Department of automation and human-machine interactions (9 Letna Str., 04100 Kosice, Slovakia).

E-mail: marek.vagas@tuke.sk

ORCID: https://orcid.org/0000-0002-8660-8484

Researcher iD: AAA-4794-2020

SCOPUS Author ID: 55014596100

Alena Galajdova - Head of the Department, Full Professor, Technical University of Kosice, Faculty of Mechanical Engineering, Department of automation and human-machine interactions (9 Letna Str., 04100 Kosice, Slovakia).

E-mail: alena.galajdova@tuke.sk

ORCID: https://orcid.org/0000-0003-0128-4191

Researcher iD: U-2074-2019

| SCOPUS Author ID: 6506796741

Vagaš, M., Galajdová, A. (2021). Industrial vision system for the detection of objects. Technical sciences and technologies, (2(24)), 99-105. 